\title{
Briefing: Specific gravity of solids relationship with ignition loss for peaty soils
}

1 Weichao Li PhD

Associate Professor, Department of Geotechnical Engineering, College of Civil Engineering, Tongji University, Shanghai, China (Orcid:00000001-9992-9300)

2 Brendan C. O'Kelly PhD, FTCD, CEng, CEnv, MICE Associate Professor, Department of Civil, Structural and Environmental Engineering, Trinity College Dublin, Dublin, Ireland (Orcid:0000-00021343-4428) (corresponding author: bokelly@tcd.ie)

3 Min Yang PhD

Professor, Department of Geotechnical Engineering, College of Civil Engineering, Tongji University, Shanghai, China
$4 \quad$ Kunbin Fang MEng Former master's student, Department of Geotechnical Engineering, College of Civil Engineering, Tongji University, Shanghai, China

5 Xuemei Li MEng PhD candidate, Department of Geotechnical Engineering, College of Civil Engineering, Tongji University, Shanghai, China

6 Hui Li PhD

Professor, Key Laboratory of Road and Traffic Engineering, Ministry of Education, Tongji University, Shanghai, China
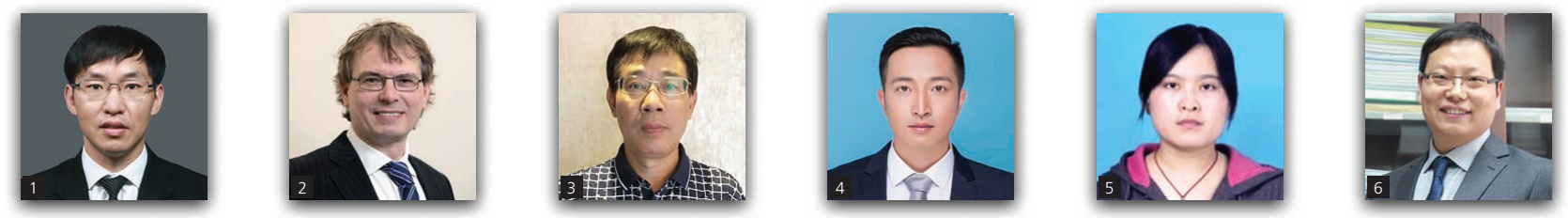

Peaty soils have an extremely high water content and a low specific gravity of solids $\left(G_{s}\right)$ compared with most inorganic soils. Accurate knowledge of the $G_{s}$ value allows void ratio computations for given water contents and densities. However, $G_{s}$ determinations using the standard pycnometer test are time consuming and pernickety, such that the $G_{s}$ value is often predicted by way of ignition loss $(N)$ correlations instead. This paper presents original $G_{s}-N$ data for 25 peaty soils $(N=23-86 \%)$ from the Dian-Chi Lake area, Kunming City, China, along with a data set assembled from various sources in the literature for 77 peaty clays and peats. The main research aim is to investigate correlations between $G_{s}$, natural water content $\left(w_{n}\right)$ and $N$ for the standard ignition temperature of $440^{\circ} \mathrm{C}$, thereby allowing indirect $G_{s}$ estimations. For the 102 peaty soils examined, the best-fit $G_{s}-N$ correlation was obtained for specific gravities of the inorganic and organic solids fraction values of 2.77 and 1.35, respectively. A weaker inverse bilinear relationship was found between $G_{s}$ and $w_{n}$. To overcome procedural differences between codes and for previous experimental work, it is recommended that an oven temperature of $105^{\circ} \mathrm{C}$ be consistently used for drying peaty soil specimens.

\section{Notation}

$A_{\mathrm{c}}, B_{\mathrm{c}}, C_{\mathrm{c}} \quad$ coefficients

$G_{\mathrm{s}} \quad$ specific gravity of soil solids

$G_{\text {s(ash) }} \quad$ specific gravity of ash residue

$G_{\text {sm }} \quad$ specific gravity of inorganic solids

$G_{\text {so }} \quad$ specific gravity of organic solids

$\mathrm{Hn} \quad$ humification number

$N \quad$ ignition loss for a temperature of $440^{\circ} \mathrm{C}$

$N^{\prime} \quad$ ignition loss for a temperature of $550^{\circ} \mathrm{C}$

$P \quad$ organic matter content

$R^{2} \quad$ coefficient of determination

$T_{\mathrm{LOI}} \quad$ ignition temperature

$w_{\mathrm{n}} \quad$ natural water content

$\sigma \quad$ standard deviation

\section{Introduction}

Surficial peat deposits cover large areas of the world's land mass, and peaty soil layers can occur at depth. Compared with most inorganic soils, these materials generally have an extremely high water content, a high organic content, a low specific gravity of solids and hence low bulk and dry density values. For instance, the natural (in situ) gravimetric water content $\left(w_{\mathrm{n}}\right)$ typically ranges from approximately 200 to $2000 \%$ (Hobbs, 1986; Mesri and Ajlouni, 2007; O'Kelly, 2015; O'Kelly and Sivakumar, 2014) for heavily consolidated decomposed (amorphous) peat deposits and coarse-fibrous surficial peat deposits, respectively. As an important physical property, the specific gravity of solids $\left(G_{\mathrm{s}}\right)$ is defined as the ratio of the mass of dry solid particles to the mass of de-aired distilled water they displace, and its value is usually referenced to a standard temperature of $20^{\circ} \mathrm{C}$ (ASTM, 2014a; BSI, 1990a). Accurate knowledge of the $G_{\mathrm{s}}$ value allows the determination of the void ratio (among other basic parameters) for given soil densities and water contents. The definitive geotechnical laboratory approach for specific gravity determinations is the pycnometer method, which is performed on the soil fraction with particles sizes $<2 \mathrm{~mm}$ (BS EN 1377-2:1990 (BSI, 1990a)) or $<4.75 \mathrm{~mm}$ (ASTM D 854-14 (ASTM, 2014a)). Standard oven temperature ranges of $105-110^{\circ} \mathrm{C}$ (BSI, 1990a) 
and $110 \pm 5^{\circ} \mathrm{C}$ (ASTM, 2014a) are specified for oven-drying of the soil material used in performing pycnometer tests.

Total volatile solids (loss on ignition, $N$ ), as determined by the percentage reduction in the mass of an oven-dried test specimen on ignition in a muffle furnace at a standard temperature of $440 \pm$ $40^{\circ} \mathrm{C}$ (ASTM, 2014b; BSI, 1990b), is used as an indirect measure of the organic matter content $(P)$. For this ignition temperature value, the inorganic solids fraction is assumed inert and it remains as the ash residue in the specimen crucibles, with the $N$ value (as $\%$ ) calculated as 100 minus the percentage ash content. It should be noted that different oven-drying temperature ranges of $110 \pm$ $5^{\circ} \mathrm{C}$ (ASTM, 2014b) and $50.0 \pm 2.5^{\circ} \mathrm{C}$ (BSI, 1990b) are specified for preparing the dried ignition specimens. For peat and other organic soils, increasing humification levels achieved over time cause a decrease in the soil's organic fraction relative to its higher specific gravity inorganic fraction, such that as the $N$ value decreases, the specific gravity of soil solids increases. The rate and extent of this time-dependent process and its various controlling geoenvironmental factors $(\mathrm{pH}$, carbon $(\mathrm{C})$ ):nitrogen $(\mathrm{N})$ ratio, aeration level, temperature) have been investigated for peat (O'Kelly and Pichan, 2013, 2014; Wardwell et al., 1983) and for municipal organic sludge and residue materials (O'Kelly, 2008, 2016; Zhan et al., 2014).

The pycnometer method for specific gravity determinations is a pernickety and time-consuming test to perform, particularly for peaty soils (O'Kelly, 2018, 2019). In this regard, the loss on ignition $N$ is a useful index property, serving as a convenient, quicker and reliable means for specific gravity determination, with $N$ correlating strongly with $G_{\mathrm{s}}$ for various organic soils according to the following (see the Appendix (which also includes Figure 7) for equation derivation).

$$
\text { 1. } G_{\mathrm{s}}=\frac{A_{\mathrm{c}}}{N B_{\mathrm{c}}+C_{\mathrm{c}}}
$$

where coefficients $A_{\mathrm{c}}, B_{\mathrm{c}}$ and $C_{\mathrm{c}}$ are functions of the specific gravities of the inorganic and organic solids $\left(G_{\mathrm{sm}}\right.$ and $G_{\mathrm{so}}$, respectively) - that is, $A_{\mathrm{c}}=G_{\mathrm{sm}} \times G_{\mathrm{so}}, B_{\mathrm{c}}=G_{\mathrm{sm}}-G_{\mathrm{so}}$ and $C_{\mathrm{c}}=G_{\mathrm{so}}$.

For example, $G_{\mathrm{s}}-N$ relationships of the form given by Equation 1, with $G_{\mathrm{sm}}=2.7$ and $G_{\mathrm{so}}=1.4$, were employed by Skempton and Petley (1970), Hobbs (1986) and Den Haan and Kruse (2007) for peat and organic clay materials. Moo-Young and Zimmie (1996) employed $G_{\mathrm{sm}}=2.5-2.75$ and $G_{\mathrm{so}} \approx 1.5$ for paper mill sludge, and O'Kelly (2018) employed $G_{\text {sm }}=2.65$ and $G_{\text {so }}=1.32$ for sewage sludge and biosolid materials. The dissimilarities in the specific gravity values for the inorganic and organic fractions of these materials are simply explained by inherent differences in the nature (origin) of their inorganic and organic matter fractions resulting in their different mineralogical and organic compositions (O'Kelly, 2018). The original research in this area was performed by Skempton and Petley (1970), who investigated the $G_{\mathrm{s}}-N$ correlation obtained for 28 samples, comprising 20 peaty clay and peat (H8-H9; $N=1.9-74.7 \%$ ) samples from Avonmouth, six fen peat samples (H5-H7: moderately and slightly fibrous materials; $N=$ 16.2-82.5\%) from King's Lynn and two Sphagnum peat samples (H3 and H5: fibrous and moderately fibrous; $N=98.7$ and 98.8\%) from Cranberry Moss, England. Here, the degree of decomposition of the organic fraction is categorised by determining its humification number $(\mathrm{Hn})$ on the von Post classification scale of $\mathrm{H} 1$ to H10 (von Post and Granlund (1926) and also described in the papers by Landva and Pheeney (1980) and Hobbs (1986), to name a few) - that is, the plant structure can range from easily identifiable (H1) to not discernible (completely decomposed state (H10)).

In performing ignition loss tests on peaty soils, Hobbs (1986) followed the British Standard method (BSI, 1990b) - that is, employing an ignition temperature $\left(T_{\mathrm{LOI}}\right)$ of $440 \pm 40^{\circ} \mathrm{C}$. Den Haan and Kruse (2007) reported oven-drying at $105^{\circ} \mathrm{C}$ for water content determinations, with Dutch practice prescribing an ignition temperature of $500^{\circ} \mathrm{C}$ for a $4 \mathrm{~h}$ period. Skempton and Petley (1970) also oven-dried peaty soils at $105^{\circ} \mathrm{C}$ for water content determinations and for drying the specimens to a constant mass in performing the ignition loss tests, but they employed a higher $T_{\mathrm{LOI}}$ value of $550^{\circ} \mathrm{C}$, with the specimen constant mass condition attained within $3 \mathrm{~h}$.

O'Loughlin and Lehane (2003) reported that for all practical purposes, $N$ values measured for oven-drying at $110 \pm 5^{\circ} \mathrm{C}$, followed by ignition at $440 \pm 40^{\circ} \mathrm{C}$, can be taken as equal to the organic content value. Hobbs (1986) and O'Kelly (2019) concluded that the measured $N$ values for peaty soils and biosolid materials, employing an oven-drying temperature of $105^{\circ} \mathrm{C}$ followed by ignition testing at $440 \pm 40^{\circ} \mathrm{C}$, are the same as their organic matter content $(P)$ values for $N>10 \mathrm{wt} \%$. Den Haan and Kruse (2007) arrived at the same conclusion, but for employing the higher $T_{\mathrm{LOI}}$ value of $500^{\circ} \mathrm{C}$ adopted in Dutch practice. On the other hand, Skempton and Petley (1970) applied a small correction to the measured ignition loss value for $550^{\circ} \mathrm{C}$ (i.e. $N^{\prime}$ ) in order to account for physiochemical changes to the inorganic solids occurring for the higher $T_{\mathrm{LOI}}$ value - that is, according to Skempton and Petley (1970), the organic content $(P=N)$ value used in Equation 1 is computed as follows.

\section{2. $N=1.04 N^{\prime}-4 \quad(N>10 \%)$}

where $N^{\prime}$ is the ignition loss determined for oven-drying at $105^{\circ} \mathrm{C}$ followed by ignition at $550^{\circ} \mathrm{C}$.

Compared with the standard oven-drying temperature ranges of $105-110^{\circ} \mathrm{C}$ (BSI, 1990a) and $110 \pm 5^{\circ} \mathrm{C}$ (ASTM, 2014a) employed for performing pycnometer tests on peat and other highly organic soils, some researchers opt for lower drying temperatures in the range $60-70^{\circ} \mathrm{C}$ (Madaschi and Gajo, 2015; $\mathrm{Ng}$ and Eischens, 1983). Also, as described earlier, there are significant differences in the oven temperatures specified in codes 
for preparing dried test material for ignition loss testing - that is, oven temperature ranges of $110 \pm 5^{\circ} \mathrm{C}$ (ASTM, 2014b) and $50 \pm$ $2.5^{\circ} \mathrm{C}$ (BSI, 1990b). As some organic matter present in peaty soils may be susceptible to charring/oxidation and (or) vaporisation for oven temperatures above $80-90^{\circ} \mathrm{C}$ (Hosang and Locker, 1971; MacFarlane and Allen, 1965; O'Kelly, 2004, 2005) and with residual pore water remaining for oven temperatures below $100^{\circ} \mathrm{C}$, the disparity in the various oven temperatures employed for preparing the dried test specimens inevitably has knock-on effects for the measured $G_{\mathrm{s}}$ and $N$ values. After quantifying the countering effects of organic solids mass loss and residual pore water mass, O'Kelly (2019) concluded that the measurement of ignition loss based on the lower oven-drying temperature range $50.0 \pm 2.5^{\circ} \mathrm{C}$ should be avoided since it results in an overprediction of total volatile solids. In other words, vaporisation of residual pore water remaining in test specimens oven-dried at $50 \pm 2.5^{\circ} \mathrm{C}$ is taken as a loss in dry solids from the point of view of performing the ignition loss calculations. Further, the $T_{\mathrm{LOI}}$ value employed can vary from the standard temperature range $440 \pm 40^{\circ} \mathrm{C}$ (ASTM, 2014b; BSI, 1990b) to $500^{\circ} \mathrm{C}$ (Den Haan and Kruse, 2007), $550^{\circ} \mathrm{C}$ (Skempton and Petley, 1970) and as high as $800^{\circ} \mathrm{C}$ (Yamaguchi et al., 1985). Consequently, this disparity in ignition temperatures employed also has a knock-on effect for the measured ignition loss, with (marginally) higher $N$ values deduced for higher $T_{\mathrm{LOI}}$ values (e.g. see Equation 2 after Skempton and Petley (1970)) on account of unintended losses in the inorganic solids mass.

In the present study, the authors explore the $G_{\mathrm{s}}-N$ relationship for the estimation of the specific gravity of solids for peaty soils from their measured $N$ values. In the first instance, an original data set obtained by performing a range of standard index tests (including natural water content $\left(w_{\mathrm{n}}\right)$, specific gravity of soil solids $\left(G_{\mathrm{s}}\right)$ and ignition loss (for $N=23-86 \%$ )) on 25 peaty soil materials retrieved from the Dian-Chi Lake area, Kunming City, China, is presented. This number of different peaty soils is similar to that employed in the Skempton and Petley (1970) investigation (28 peat and peaty clay samples in total). Measurements of the specific gravity of the ash residue $G_{\mathrm{s}(\text { ash })}$ for organic/peaty soils are rarely reported. In fact, a review of the pertinent literature revealed only one instance, after Madaschi and Gajo (2015), who reported $G_{\mathrm{s}}$ and $G_{\mathrm{sm}}$ values for three organic soils $(N=19.9-71.0 \%)$. Hence, as well as the specific gravity of solids $\left(G_{\mathrm{s}}\right)$, the specific gravity of the ash residue was also measured for the 25 Dian-Chi peaty soils. Using this data set, the $G_{\mathrm{s}}-N$ expression given by Equation 1 was examined, back-calculating the values of $A_{\mathrm{c}}, B_{\mathrm{c}}$ and $C_{\mathrm{c}}$ based on the 'goodness of fit' to the experimental data. The Dian-Chi data set is complemented with a larger data set comprising 77 peaty soils compiled from various sources in the published literature. Discrepancies between these data and the deduced $G_{\mathrm{s}}-N$ correlation for the Dian-Chi peaty soils are investigated and explained in terms of the earlier described differences in standard oven-drying and ignition temperature values specified in different codes and also those subjectively chosen values employed by some researchers. Alternative correlations with the natural water content for obtaining the specific gravity of solids $G_{\mathrm{s}}$ are also examined. Finally, the research conclusions are presented, including recommendations on appropriate oven-drying and ignition temperatures for use in performing routine specific gravity and ignition loss testing on peats and other highly organic soils in order to obtain reliable results.

\section{Experimental materials and methods}

A total of 25 peaty soil samples were retrieved from depths between 6.6 and $9.5 \mathrm{~m}$ below ground level (bgl), with the groundwater table at approximately $1 \mathrm{~m} \mathrm{bgl}$, at a site located on the north-east shore of Dian-Chi Lake, Kunming City, Yunnan, China. Sampling in peaty soils is generally a very crucial issue for instance, the natural water content of material sampled from surficial peat deposits could be easily reduced during the sampling process on account of its highly compressible nature, particularly for more fibrous peat (O'Kelly, 2006). Since one of the stated aims of the present research was investigation of the $w_{\mathrm{n}}-G_{\mathrm{s}}$ correlation, undisturbed samples of the Dian-Chi peaty layers were obtained using a special ring-lined split-barrel sampler with inner and outer diameters of 96 and $108 \mathrm{~mm}$, respectively (see Figure 1). On extraction, the soil cores are retained inside two steel tubes positioned within the splitting tube segment of the sampling tool. High-quality samples of the Dian-Chi peaty layers were obtained given the firm consistency of these peat deposits, their largely amorphous state and the specialised sampling equipment employed. Figure 2 shows some photographs of the recovered peaty soils.

As a general comment, the sample quality could be significantly affected for sampling in fibric peat deposits on account of coarse peat fibres tending to wrap around the tip edge of the advancing sampler, interfering with the peat core entry into the relatively small-diameter sampling tube. This would cause considerable sample disturbance, including preloading (densification) and a reduction in water content for the obtained peat core. As such, it is advised that the amount of peat compression in piston samples should always be measured. For fibric peat deposits, block samples are recommended, and if this is not possible, sampling tubes should have serrated edges and be penetrated into the peat by combined twisting and pushing (Long and Boylan, 2013).

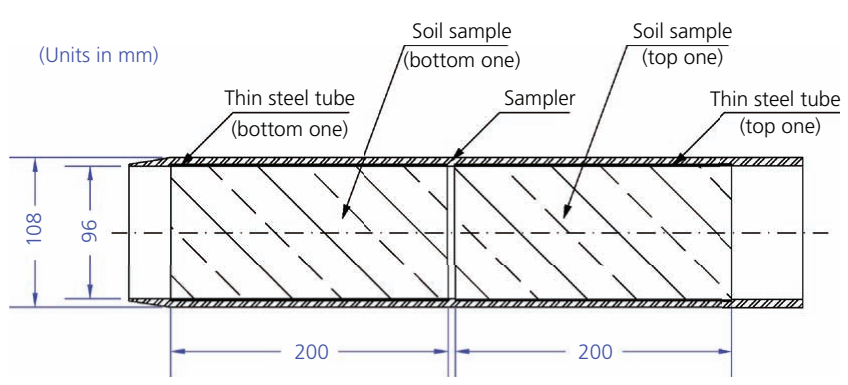

Figure 1. Ring-lined split-barrel sampler used to retrieve the largely amorphous peaty soil cores (Li et al., 2020) 
Briefing: Specific gravity of solids relationship with ignition loss for peaty soils

Li, O’Kelly, Yang et al.

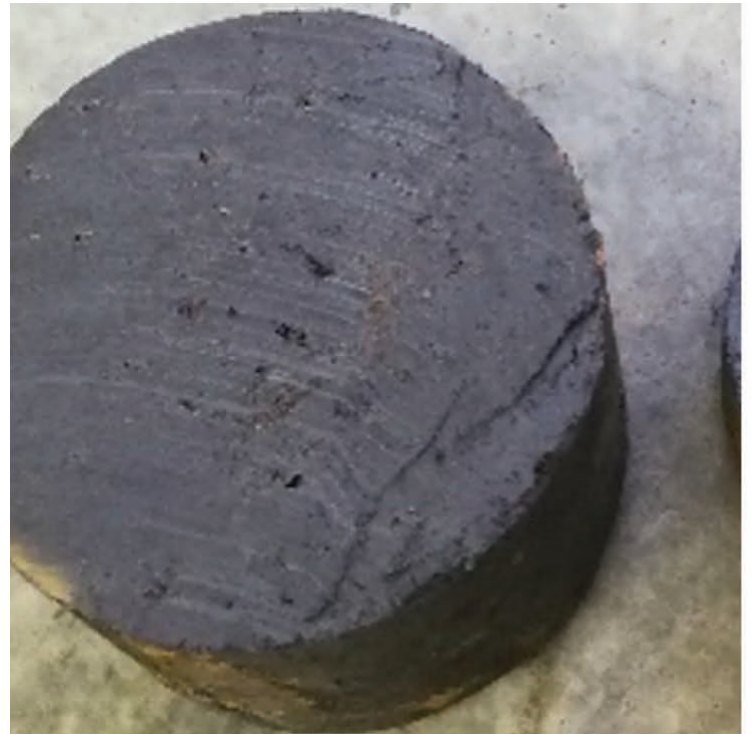

(a)

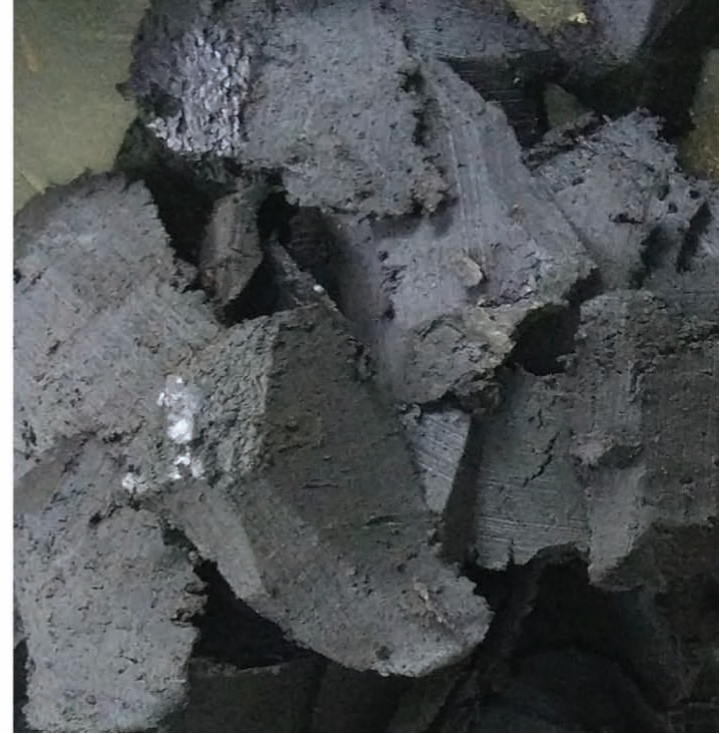

(b)

Figure 2. Sampled largely amorphous peaty soils retrieved from $8.4 \mathrm{~m}$ depth at the Dian-Chi Lake area using the sampler shown in Figure 1: (a) recovered core $\left(w_{n}=142 \%, N=23.5 \%\right)$; (b) sample trimmings $\left(w_{n}=192 \%, N=34.8 \%\right)$

The sequence of laboratory testing and associated specimen preparation methods performed for the obtained Dian-Chi peaty soils are explained using the flow chart presented in Figure 3. To investigate the specific gravity of the organic and inorganic solids fractions separately, a series of pycnometer tests was performed following ASTM D 854-14 (ASTM, 2014a). Based on the research findings and recommendations of $\mathrm{Li}$ et al. (2020), O'Kelly (2014), O'Kelly and Li (2018), O'Kelly and Sivakumar

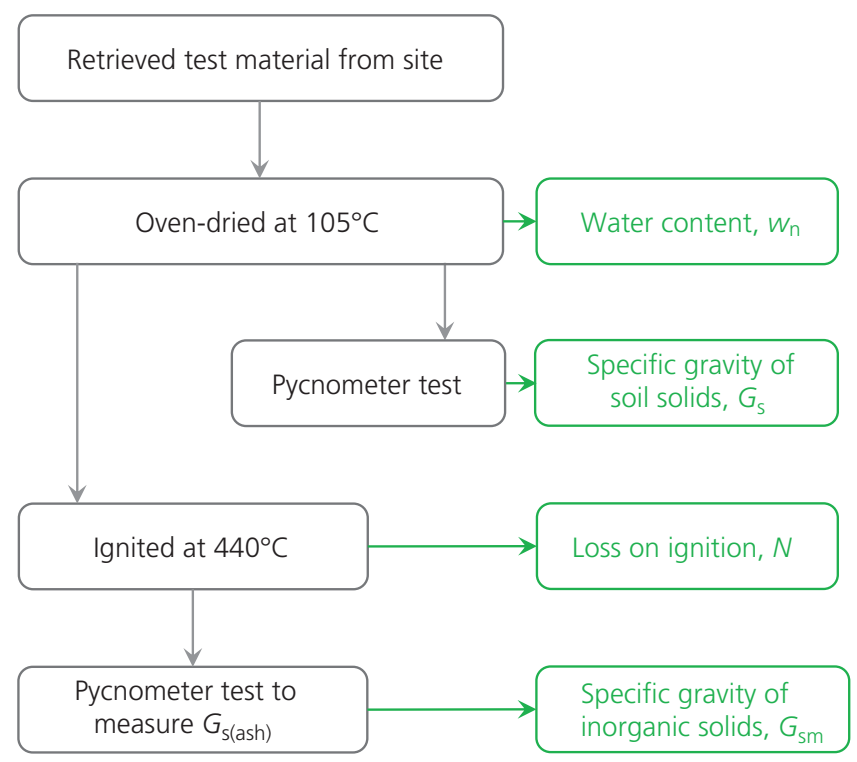

Figure 3. Flow chart for testing programme on deep peaty soils retrieved from the Dian-Chi Lake area, China
(2014) and Skempton and Petley (1970), an oven-drying temperature of $105^{\circ} \mathrm{C}$ was employed for all water content determinations and in oven-drying the test materials for both specific gravity and ignition loss testing. As described earlier, peaty soils regularly contain organic fibrous material, some of which may be susceptible to charring/oxidation for temperatures above $80-90^{\circ} \mathrm{C}$. Residual pore water remaining in the dried test specimen for oven temperatures below $100^{\circ} \mathrm{C}$ also introduces errors for water content determinations. When these counteracting effects were examined, the previously mentioned researchers concluded that an oven-drying temperature of $105^{\circ} \mathrm{C}$ is acceptable for routing water content determinations on (fibrous) peats and other highly organic soils. Hobbs (1986) is also of the same view.

For each peaty soil sample, the oven-dried material was divided into two portions. One portion was used for pycnometer testing to measure the specific gravity of soil solids $G_{\mathrm{s}}$ (i.e. for the combined organic and inorganic solids fractions). For inorganic soils, apart from those containing soluble salts, demineralised water is employed as the liquid in the density bottles. Demineralised water has also been used for specific gravity testing of peat materials ( $\mathrm{Ng}$ and Eischens, 1983), but kerosene is often used instead (e.g. Hobbs, 1986; Skempton and Petley, 1970), with a separate experiment performed to determine the density of the kerosene at the temperature of the test. Compared with water, the lower density kerosene avoids floatation of lightweight organic solids and prevents possible biodegradation of susceptible organic matter present in the test specimens during the course of the pycnometer testing (O'Kelly, 2018, 2019). Hence, kerosene was used as the liquid in the density bottles for the present investigation. 
The second portion of each oven-dried sample was ignited in a muffle furnace at $440^{\circ} \mathrm{C}$ (ASTM, 2014b; BSI, 1990b) for the determination of its ignition loss value. Pycnometer tests were subsequently performed on the ash residue for determination of its specific gravity, in this case employing distilled water as the density liquid since the ash residue is inert and has a much higher specific gravity compared with water.

The widely used von Post hand-squeeze test (von Post and Granlund, 1926) was performed on representative subsamples. This test examines the peaty soil in the hand regarding its wetness, level of decay and its fibre and shrub constituents, with the degree of decomposition of the organic fraction categorised by determining its humification number $(\mathrm{Hn})$ in the range of $\mathrm{H} 1$ to H10. The determination of the fibre content of the sampled materials was deemed not necessary given their largely amorphous states.

\section{Experimental results and analysis}

Table 1 lists the values of natural water content $\left(w_{\mathrm{n}}\right)$, specific gravity of soil solids $\left(G_{\mathrm{s}}\right)$, ignition loss $(N)$ and specific gravity of the ash residue $\left(G_{\mathrm{s}(\mathrm{ash})}\right)$ measured for the 25 Dian-Chi peaty soil samples retrieved from various depths, with $w_{\mathrm{n}}$ ranging $142-392 \%, N=23-86 \%, G_{\mathrm{s}}=1.43-2.23$ and $G_{\mathrm{s}(\mathrm{ash})}=2.74-3.30$. On the von Post humification scale, the organic fractions of these peaty soils were classified as highly decomposed, with humification numbers ranging $\mathrm{H} 7-\mathrm{H} 10$. The parent organic material from which the peaty soil layers were formed was mainly

Table 1. Some physical properties of retrieved samples from the Dian-Chi Lake area, China

\begin{tabular}{|c|c|c|c|c|}
\hline Depth: m bgl & $w_{n}: \%$ & $N: \%$ & $\mathbf{G}_{\mathrm{s}}$ & $G_{\text {s(ash) }}$ \\
\hline 6.6 & 383 & 83.0 & 1.51 & 3.30 \\
\hline 6.7 & 364 & 78.0 & 1.49 & 3.20 \\
\hline 6.8 & 365 & 73.4 & 1.60 & 2.95 \\
\hline 6.9 & 340 & 74.5 & 1.63 & 2.96 \\
\hline 7.1 & 392 & 86.1 & 1.43 & 3.25 \\
\hline 7.2 & 350 & 76.4 & 1.50 & 3.12 \\
\hline 7.4 & 321 & 71.0 & 1.57 & 3.00 \\
\hline 7.6 & 238 & 42.0 & 1.81 & 2.88 \\
\hline 7.8 & 208 & 44.0 & 1.83 & 2.86 \\
\hline 8.0 & 191 & 35.5 & 2.05 & 2.82 \\
\hline 8.0 & 177 & 33.9 & 2.06 & 2.79 \\
\hline 8.2 & 216 & 42.7 & 1.95 & 2.85 \\
\hline 8.2 & 191 & 34.6 & 2.05 & 2.78 \\
\hline 8.2 & 185 & 32.5 & 2.09 & 2.76 \\
\hline 8.3 & 187 & 31.7 & 2.05 & 2.78 \\
\hline 8.4 & 192 & 34.8 & 2.09 & 2.76 \\
\hline 8.4 & 142 & 23.5 & 2.21 & 2.78 \\
\hline 8.7 & 143 & 26.8 & 2.23 & 2.77 \\
\hline 9.0 & 200 & 36.0 & 2.00 & 2.77 \\
\hline 9.0 & 177 & 30.6 & 2.09 & 2.74 \\
\hline 9.1 & 195 & 36.3 & 2.02 & 2.77 \\
\hline 9.2 & 253 & 47.9 & 1.88 & 2.84 \\
\hline 9.2 & 206 & 38.8 & 1.86 & 2.78 \\
\hline 9.3 & 177 & 32.9 & 2.12 & 2.76 \\
\hline 9.5 & 217 & 37.8 & 1.94 & 2.77 \\
\hline
\end{tabular}

Phragmites plants. No information was gathered on the chemical and mineralogical properties of these soils.

Specific gravity of ash residue, $G_{s(a s h)}$

Figure 4 presents the measured specific gravity against ignition loss data for the 25 Dian-Chi peaty soils investigated. Referring to Figure 4(a) and considering $G_{\mathrm{sm}} \approx 2.60-2.80$ (Huat et al., 2014) for most inorganic fine-grained soils, it is concluded that excessively high $G_{\mathrm{s}(\mathrm{ash})}$ values between 2.84 and 3.30 were measured for $N>40 \%$, which comprised 11 of the 25 peaty soils investigated. This was not expected. Again, referring to this figure, the $G_{\mathrm{s}(\text { ash })}$ increases in value with increasing $N$ for $N>$ $40 \%$. The reason for this is not clear, although it is not thought to be procedurally related, since all soil samples investigated were retrieved from the same geographic location and then tested using the same experimental procedures. It is hypothesised that for $N>$ $40 \%$, the $T_{\text {LOI }}$ value of $440^{\circ} \mathrm{C}$ used brought about significant physico-chemical changes for the ash material. As such, these $G_{\text {s(ash) }}$ values are not regarded as credible measures of $G_{\mathrm{sm}}$.

As evident from Figure 4(a), for the 14 soils (with $N=$ 23.5-38.8\%), the measured value of $G_{\text {s(ash) }}$ was independent of $N$ for practical purposes, with the mean value of $G_{\mathrm{s}(\text { ash })}=2.77$ (standard deviation of $\sigma=0.02$ ) falling within the generally accepted range of $G_{\mathrm{s}}=2.60-2.80$ for inorganic fine-grained soils. The narrow standard deviation value of 0.02 obtained for $G_{\mathrm{s}(\mathrm{ash})}$ with $N<40 \%$ is also consistent with the likely similar mineralogy of the various samples retrieved from the same Dian-Chi sampling location. Based on the above observations, the $G_{\mathrm{s}(\mathrm{ash})}$ value of 2.77 was taken as representative of the specific gravity of the inorganic solids $\left(G_{\mathrm{sm}}\right)$ for the 25 peaty soils.

\section{Specific gravity of organic fraction, $G_{\text {so }}$}

With the value of $G_{\mathrm{sm}}$ taken as 2.77, Equation 1 was fitted to the measured $G_{\mathrm{s}}-N$ data presented for the 25 peaty soils in Figure 4(b), producing best-fit coefficient values of $A_{\mathrm{c}}=3.74, B_{\mathrm{c}}=1.42$ and $C_{\mathrm{c}}=1.35$. This fitting has a coefficient of determination $\left(R^{2}\right)$ of 0.96 and a root-mean-squared error of 0.052 . In other words, the $G_{\mathrm{sm}}$ value of 2.77 implies a $G_{\mathrm{so}}\left(=C_{\mathrm{c}}\right)$ value of 1.35 for these 25 peaty soils. Taking a different approach, values of $G_{\text {so }}$ were also determined by back-calculation using Equation 1 for each of the 25 peaty soils, employing inputs of measured $G_{\mathrm{S}}$ and $N(=P)$ values and assuming that $G_{\mathrm{sm}}$ equals the mean $G_{\mathrm{s}(\text { ash })}$ value of 2.77 for $N<40 \%$. The deduced $G_{\text {so }}$ values ranged $1.22-1.45$ (mean of 1.35 and $\sigma=0.06$ ) and are plotted against their measured $N$ values in Figure 4(c). Both of these analysis approaches produced the same mean $G_{\text {so }}$ value (1.35). Included in Figure $4(\mathrm{c})$ are the $G_{\text {so }}$ values for three organic soils investigated in the paper by Madaschi and Gajo (2015). These $G_{\text {so }}$ values were computed as part of the present investigation from their reported measured $N$ and $G_{\text {sm }}$ values using Equation 11 reported in the Appendix. As evident from this figure, the deduced $G_{\text {so }}$ values for the present and Madaschi and Gajo (2015) investigations are in good agreement and practically independent of the $N$ value, which ranged from 20 to $86 \%$. 


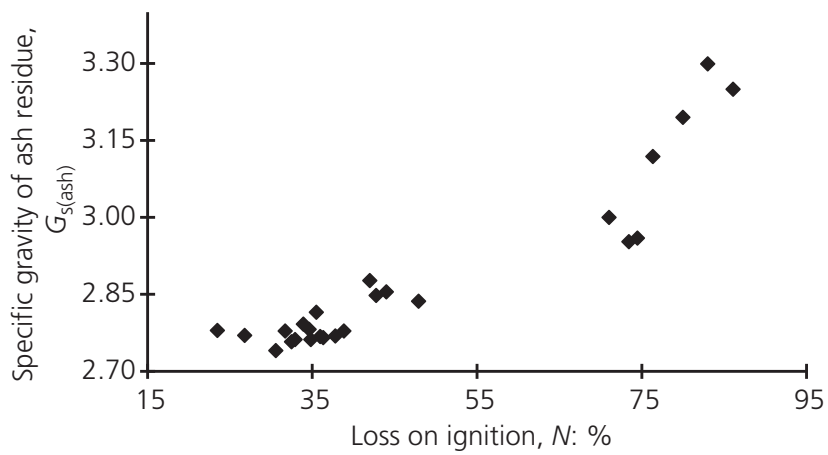

(a)

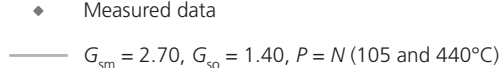

- Present investigation: $G_{\text {sm }}=2.77, G_{\text {so }}=1.35, P=N\left(105\right.$ and $\left.440^{\circ} \mathrm{C}\right)$

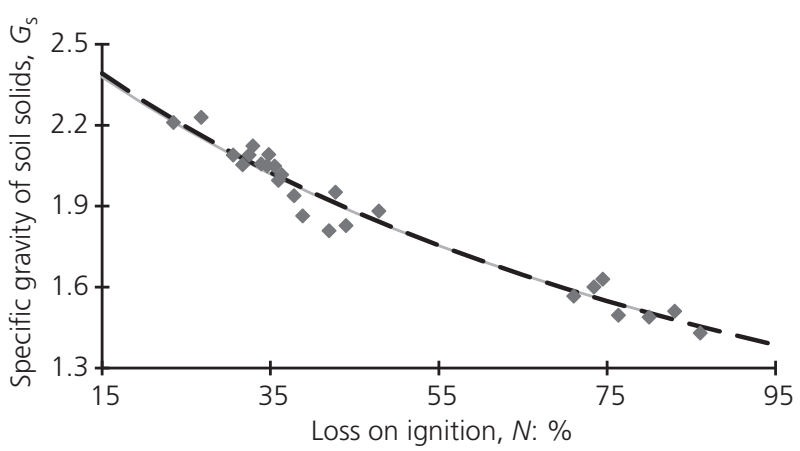

(b)

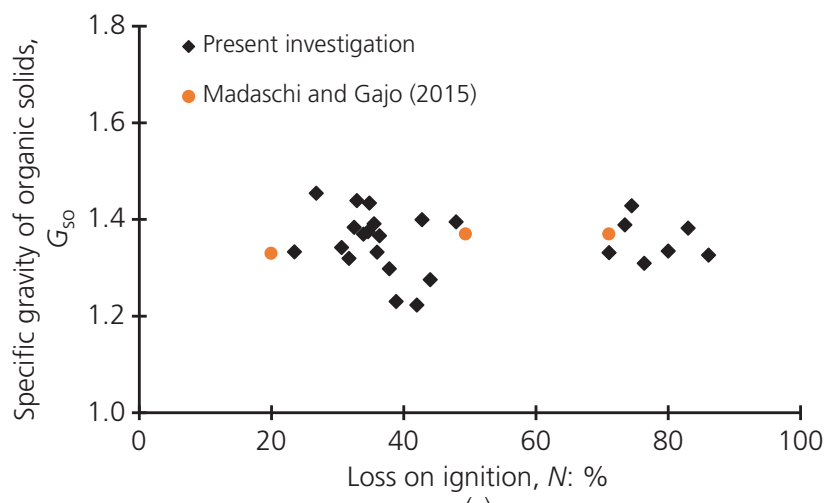

(c)

Figure 4. Specific gravity against ignition loss: (a) specific gravity of ash residue; (b) specific gravity of soil solids; (c) calculated specific gravity of organic solids

\section{Comparison of Dian-Chi $\mathbf{G}_{\mathrm{s}}-\mathrm{N}$ correlation with existing relationships for peaty soils}

Included in Figure 4(b) is the $G_{\mathrm{s}}-N$ correlation plotted for previously reported values of $G_{\mathrm{sm}}=2.7$ and $G_{\mathrm{so}}=1.4$ (Den Haan and Kruse, 2007; Hobbs, 1986; Skempton and Petley, 1970) for peat and organic clay materials. Den Haan and Kruse (2007) adopted a $T_{\mathrm{LOI}}$ value of $500^{\circ} \mathrm{C}$ and assumed $P=N$ (the present investigation took $P=N$ for $T_{\mathrm{LOI}}=440^{\circ} \mathrm{C}$ ). On the other hand, Skempton and Petley (1970) employed a higher $T_{\text {LOI }}$ value of $550^{\circ} \mathrm{C}$ for their investigation, applying Equation 2 to determine the $N(=P)$ value from the measured $N^{\prime}$ value. As such, for $T_{\mathrm{LOI}}=$ $440^{\circ} \mathrm{C}$, the Den Haan and Kruse (2007) and Skempton and Petley (1970) correlations produce practically identical results. As evident from Figure 4(b), the best-fit curve deduced in the present investigation for the 25 Dian-Chi peaty soils, with experimentally derived $G_{\mathrm{sm}}$ and $G_{\mathrm{so}}$ values of 2.77 and 1.35, respectively, is almost identical to the Den Haan and Kruse (2007) and Skempton and Petley (1970) approaches.

Wider validation of the $G_{\mathrm{s}}-N$ correlation for peaty soils In order to validate the wider application of the deduced $G_{\mathrm{s}}-N$ correlation for the Dian-Chi peaty soils, a database comprising another 77 peaty soils investigated in eight countries around the world was assembled from 13 published research papers (see Table 2). From the available information reported, it should be noted from Table 2 that these materials had widely different humification levels, with von Post $\mathrm{Hn}$ ranging between $\mathrm{H} 4$ and $\mathrm{H} 9$, along with a single $\mathrm{H} 3$ peat material. Further, different oven temperatures in the range $60-110^{\circ} \mathrm{C}$ were employed for performing the water content determinations, as well as in drying the specimens for specific gravity and ignition loss testing. Similarly, different $T_{\mathrm{LOI}}$ values in the range $440-800^{\circ} \mathrm{C}$ were employed for performing the ignition tests, although $440^{\circ} \mathrm{C}$ was the one most commonly used ignition temperature in these investigations. Also included in Table 2 are the $\mathrm{pH}$ ranges, where available, for the various peaty soils investigated in the referenced studies. The $\mathrm{pH}$ gives an insight into the nature of the peat. As a rough general rule, blanket and raised bog peats in which the acidulous Sphagnum moss is the predominant plant have $\mathrm{pH}$ values ranging from 3.3 to 4.5 , the $\mathrm{pH}$ of fen peat tends to be greater than about 5 , whereas transitional peats fall in the $\mathrm{pH}$ range from 4 to 6 (Hobbs, 1986). However, a considerable degree of overlapping can occur depending on local influences - for instance, acid fen peat will have a $\mathrm{pH}<5$. Apart from oxygen 
Table 2. $G_{s}-N$ data set compiled from the existing literature

\begin{tabular}{|c|c|c|c|c|c|c|}
\hline Country & $\begin{array}{l}\text { Number of } \\
\text { test samples }\end{array}$ & $\begin{array}{l}\text { Oven-drying } \\
\text { temperature: }{ }^{\circ} \mathrm{C}\end{array}$ & $\begin{array}{c}\text { Ignition } \\
\text { temperature: }{ }^{\circ} \mathrm{C}\end{array}$ & $\begin{array}{l}\text { von Post } \\
\text { number }\end{array}$ & $\mathrm{pH}$ & Reference \\
\hline Canada & 2 & $\mathrm{nr}, \mathrm{nr}, \mathrm{nr}$ & $\mathrm{nr}$ & $\mathrm{nr}$ & $4.8-6.7$ & Adams (1965) \\
\hline China, Dian-Chi & 25 & $105,110 \pm 5,110 \pm 5$ & 440 & $\mathrm{H} 7-\mathrm{H} 10$ & $\mathrm{nr}$ & Present investigation \\
\hline Ireland & $\begin{array}{l}1 \\
2 \\
3\end{array}$ & $\begin{array}{c}\text { 80, } \mathrm{nr}, \mathrm{nr} \\
\mathrm{nr}, \mathrm{nr}, \mathrm{nr} \\
105,105, \mathrm{nr}\end{array}$ & $\begin{array}{c}440 \\
\mathrm{nr} \\
440\end{array}$ & $\begin{array}{c}\mathrm{H} 4.5 \\
\mathrm{H} 4-\mathrm{H} 6 \\
\mathrm{H} 4-\mathrm{H} 7\end{array}$ & $\begin{array}{c}\mathrm{nr} \\
\mathrm{nr} \\
3.6-5.4\end{array}$ & $\begin{array}{l}\text { Long and Boylan (2013) } \\
\text { O'Kelly (2007) } \\
\text { O'Kelly and Sivakumar (2014) }\end{array}$ \\
\hline Italy & 3 & $60,60,60$ & $440 \pm 40$ & $\mathrm{nr}$ & $\mathrm{nr}$ & Madaschi and Gajo (2015) \\
\hline Japan & 19 & $\mathrm{nr}, \mathrm{nr}, \mathrm{nr}$ & 800 & $\mathrm{nr}$ & $5-7$ & Yamaguchi et al. (1985) \\
\hline Netherlands & $\begin{array}{l}6 \\
4 \\
5\end{array}$ & $\begin{array}{c}60,110 \pm 5, \mathrm{nr} \\
80, \mathrm{nr}, \mathrm{nr} \\
\mathrm{nr}, 110 \pm 5,105-110\end{array}$ & $\begin{array}{l}500 \\
440 \\
500\end{array}$ & $\begin{array}{c}\mathrm{nr} \\
\mathrm{H} 5.5-\mathrm{H} 6.5 \\
\mathrm{nr}\end{array}$ & $\begin{array}{l}\mathrm{nr} \\
\mathrm{nr} \\
\mathrm{nr}\end{array}$ & $\begin{array}{l}\text { Jommi et al. (2019) } \\
\text { Long and Boylan (2013) } \\
\text { Papadaki (2013) }\end{array}$ \\
\hline Malaysia & 8 & $105,110 \pm 5,105-110$ & 440 & $\mathrm{H} 3-\mathrm{H} 7$ & $3.85-6.18$ & Kolay and Rahman (2016) \\
\hline USA & $\begin{array}{l}4 \\
3\end{array}$ & $\begin{array}{c}n r, \mathrm{nr}, \mathrm{nr} \\
60-70,80,60-70\end{array}$ & $\begin{array}{c}\mathrm{nr} \\
550\end{array}$ & $\begin{array}{l}\mathrm{nr} \\
\mathrm{nr}\end{array}$ & $\begin{array}{l}6.2-7.3 \\
5.4-6.9\end{array}$ & $\begin{array}{l}\text { Dhowian and Edil (1980) } \\
\text { Ng and Eischens (1983) }\end{array}$ \\
\hline UK & 17 & $105, \mathrm{nr}, 105-110$ & 550 & $\mathrm{H} 5-\mathrm{H} 9$ & $\mathrm{nr}$ & Skempton and Petley (1970) \\
\hline
\end{tabular}

$\mathrm{nr}$, not reported; oven-drying temperature data are reported oven temperatures for water content, ignition loss and specific gravity of solids testing, respectively

supply, metabolic activity is greatly influenced by temperature, acidity and the availability of nitrogen, such that usually the lower the temperature and $\mathrm{pH}$ (higher acidity), the slower the decomposition (Hobbs, 1986; Pankratov et al., 2011; Pichan and O'Kelly, 2012, 2013). Hence, some similarities between peat materials could potentially be drawn based on their $\mathrm{pH}$, ignition loss and/or von Post Hn values. Unfortunately, the available data presented in Table 2 are too patchy for performing such analysis.

The $G_{\mathrm{s}}-N$ data for the 25 Dian-Chi peaty soils and for the 77 peaty soils summarised in Table 2 are all presented in Figure 5. Included in this figure is the $G_{\mathrm{s}}-N$ correlation given by Equation 1, with input values of $G_{\mathrm{sm}}=2.77$ and $G_{\mathrm{so}}=1.35$, which were deduced in the present investigation for the 25 Dian-Chi peaty soils. It is evident that there are varying degrees of scatter between the data sets for the various research investigations and the presented $G_{\mathrm{s}}-N$ correlation. Major contributing factors are the previously mentioned procedural differences between the various experimental investigations. For instance, compared with the $440-550^{\circ} \mathrm{C}$ ignition temperature range employed for all other investigations considered, the significantly higher $T_{\mathrm{LOI}}$ value of $800^{\circ} \mathrm{C}$ adopted in the Yamaguchi et al. (1985) study could cause some mass loss for the oven-dried inorganic

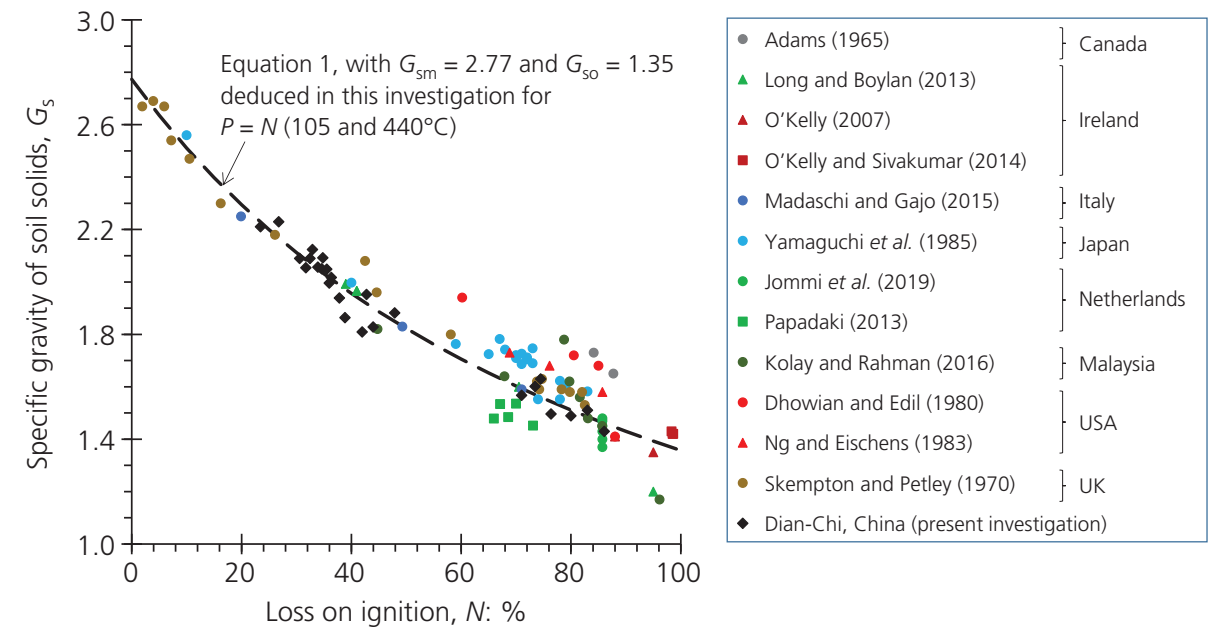

Figure 5. Specific gravity of soil solids plotted against ignition loss 
solids. This would manifest as erroneously higher measured $N$ values - that is, over-predicting the actual organic content - such that the Yamaguchi et al. (1985) data points shown in Figure 5 generally plot above the presented $G_{\mathrm{s}}-N$ correlation. Another factor is that the wood and leaf remnants in peaty soils from different parts of the world, and even for closely spaced sampling points within the same peat deposit, can have different botanical origins and hence slightly different physiochemical properties (Den Haan and Kruse, 2007; O'Kelly, 2017). Similarly, the specific gravity of the inorganic solids fraction depends on its mineralogical composition. However, since sufficient details on botanical origin and mineralogical composition were not reported in the research papers, it is not possible to establish the relative significance of their effects as part of the present investigation. Overall, however, the goodness of fit of the correlation curve confirms that Equation 1, with input values of $G_{\mathrm{sm}}=2.77$ and $G_{\text {so }}=1.35$ (deduced for an oven temperature of $105^{\circ} \mathrm{C}$ used in drying specimens for specific gravity and ignition loss testing and adopting the standard ignition temperature of $440^{\circ} \mathrm{C}$ (ASTM, 2014b; BSI, 1990b)), is appropriate for peaty soils.

\section{Investigating $w_{n}-G_{s}$ correlation for peaty soils}

Figure 6(a) shows the relationship between the measured specific gravity of solids and natural water content values for the 25 DianChi H7-H10 peaty soils, with a trend of decreasing $G_{\mathrm{s}}$ for increasing water content from 142 to $392 \%$, according to the strong correlation given by Equation 3. The form of this equation was inspired by the correlation relating dry density to water content for organic soils presented by Al-Raziqi et al. (2003) and cited by Huat et al. (2014).

$$
\begin{aligned}
& G_{\mathrm{s}}=5.974\left(w_{\mathrm{n}}+2.058\right)^{-0.785} \text { for } w_{n} \\
& \text { 3. } \quad \leq 400 \%\left(n=25, R^{2}=0.95\right)
\end{aligned}
$$

The relationship given by Equation 3 for these strongly to completely decomposed peaty soils and peats can be explained as follows. The Dian-Chi peaty soils were sampled at the same test

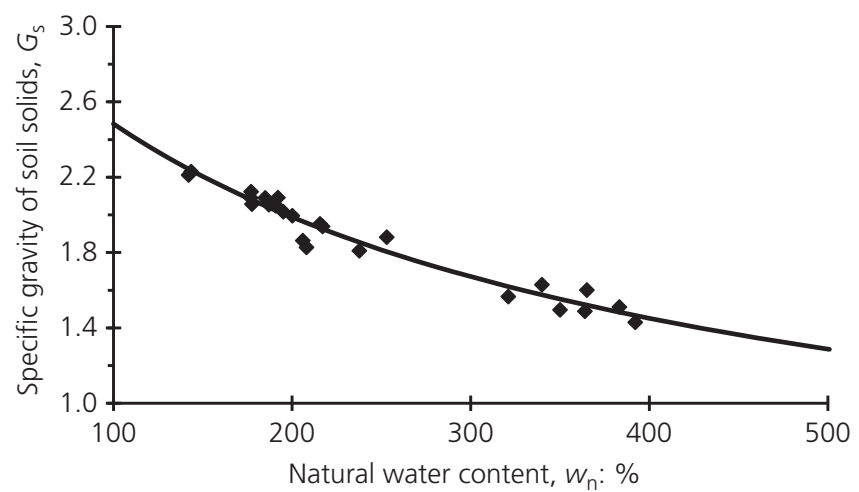

(a) site from depths ranging between 6.6 and $9.5 \mathrm{~m} \mathrm{bgl}$ (refer to Table 1). Samples retrieved from greater depths experienced greater overburden pressure and hence had undergone greater compression, such that they had lower in-situ natural water content (void ratio) values. Further, these samples would typically have higher humification levels and lower organic content, simply because deeper organic deposits had longer periods for decomposition to occur in situ, meaning that they would generally have higher $G_{\mathrm{s}}$ values. In other words, the depositional and stress histories are significant factors affecting the $w_{\mathrm{n}}-G_{\mathrm{s}}$ interrelationship, with both of them generally heavily site specific. This point is highlighted by considering the combined data for the 25 Dian-Chi peaty soils and the very diverse peaty soils listed in Table 2, which include surficial, normally and over-consolidated peaty deposits for $w_{\mathrm{n}}$ ranging between 20 and $1300 \%$ and von Post $\mathrm{Hn}$ essentially ranging $\mathrm{H} 4$ to $\mathrm{H} 9$. As evident from Figure 6(b), an entirely different and weaker correlation, given by Equation 4, is obtained for the combined data sets (excluding the five soils investigated by Papadaki (2013) since their water content values were not reported in the original paper).

$$
\begin{aligned}
G_{\mathrm{s}} & =2.267\left(w_{\mathrm{n}}+0.080\right)^{-0.189} \text { for } 400 \%<w_{n} \\
& <1300 \%\left(n=97, R^{2}=0.72\right)
\end{aligned}
$$

Overall, compared with other possible relationships and considering all 97 data points for the essentially H4 to H10 peaty soils and peats, the fitted bilinear relationship given by Equations 5 and 6 produces the strongest correlation based on having the highest $R^{2}$ value of 0.81 .

5. $G_{\mathrm{s}}=-0.3453 w_{\mathrm{n}}+2.738$ for $w_{n}<326 \%$

Figure 6. Correlation between specific gravity of soil solids and natural water content: (a) Dian-Chi peaty soils in present investigation; (b) combined data sets in Tables 1 and 2

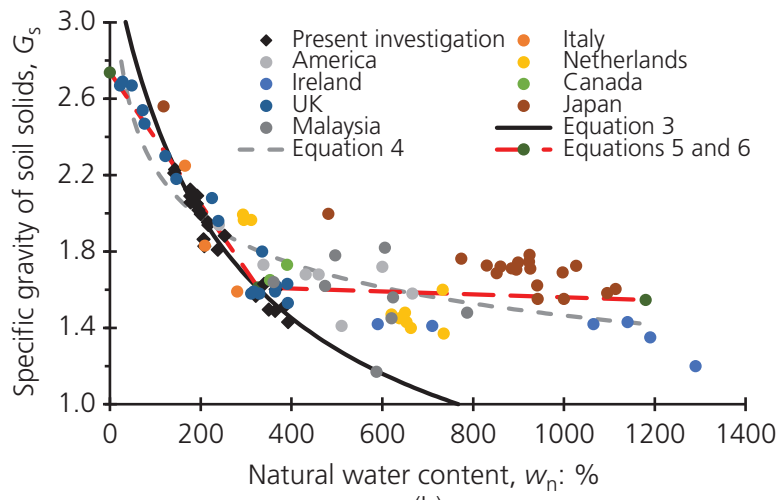

(b) 


\section{Discussion}

For the Dian-Chi H7-H10 peaty soils, employing $105^{\circ} \mathrm{C}$ for ovendrying and an ignition temperature of $440^{\circ} \mathrm{C}$, the measured value of $G_{\text {s(ash) }}$ was independent of $N$ for $N=23.5-38.8 \%$, with the mean $G_{\text {s(ash) }}$ value of $2.77(\sigma=0.02)$, such that $G_{\text {sm }} \approx 2.77$. Then, using Equation $1, G_{\mathrm{so}}$ was deduced as $1.35(\sigma=0.06)$, which is very close to the commonly assumed specific gravity value of 1.4 for the organic solids fraction in (fibrous) peaty soils (Den Haan and Kruse, 2007; Hobbs, 1986; O'Kelly and Pichan, 2013; Skempton and Petley, 1970) and almost identical to the mean $G_{\text {so }}$ value of 1.36 , for $N=19.9-71.0 \%$, computed from the data reported by Madaschi and Gajo (2015). The best-fit correlation curve given by Equation 1, with the Dian-Chi deduced $G_{\mathrm{sm}}=2.77$ and $G_{\mathrm{so}}=1.35$ values as inputs, is practically identical to the Den Haan and Kruse (2007) and Skempton and Petley (1970) approaches using $G_{\mathrm{sm}}=2.7$ and $G_{\text {so }}=$ 1.4 (Figure 4(b)). When the Dian-Chi peaty soil results were combined with data for another 77 peaty soils reported in the literature (i.e. 102 peaty soils in total, with von Post Hn essentially ranging $\mathrm{H} 4$ to $\mathrm{H} 10$ ), varying degrees of data scatter occurred for the various experimental investigations on account of material-specific as well as procedural differences between them. Material differences arise from different mineralogical compositions and botanical origins for the inorganic and organic solids fractions, such that it would not be surprising for peaty soils from different parts of the world, and even for those from closely spaced sampling points within the same peat deposit, to have some variations in their respective $G_{\text {sm }}$ and $G_{\text {so }}$ values. Procedural differences include different oven-drying temperatures in the range $60-110^{\circ} \mathrm{C}$ employed for water content determinations and in drying specimens for ignition loss and specific gravity testing, as well as different $T_{\mathrm{LOI}}$ values in the range of 440 and $800^{\circ} \mathrm{C}$ employed for the ignition tests, although $440^{\circ} \mathrm{C}$ is now typically the norm. To overcome discrepancies in experimental results arising from these procedural differences, it is the authors' contention that an oven temperature of $105^{\circ} \mathrm{C}$ be consistently used in drying peaty specimens for specific gravity and ignition loss testing, employing the standard ignition temperature of $440^{\circ} \mathrm{C}$. Overall, the $G_{\mathrm{s}}-N$ correlation for $G_{\mathrm{sm}}=2.77$ and $G_{\mathrm{so}}=1.35$ values deduced in the present study produces a good fit to the data points for the 102 peaty soils, providing further validation of the $G_{\mathrm{s}}-N$ correlation/ relationship originally proposed by Skempton and Petley (1970) based on data for only 28 peaty soils (H3 to H9).

A weaker inverse relationship was found between the natural water content and specific gravity of solids, the basis of which is that lower-water-content samples retrieved from greater depths (overburden pressure) would have experienced higher compression (consolidation) and humification levels and hence have lower water and organic contents but higher specific gravities of soil solids. Two inverse power $w_{\mathrm{n}}-G_{\mathrm{s}}$ correlations were presented: Equation 3 for heavily consolidated and largely amorphous peaty soil deposits (i.e. $w_{\mathrm{n}} \leq 400 \%$ and von Post H7-H10) and Equation 4 for surficial and lightly consolidated peaty soil deposits (i.e. $400 \%<w_{\mathrm{n}}<1300 \%$ ). Overall, considering all entries in the database, the strongest correlation covering the full water content range investigated was achieved with the bilinear relationship given by Equations 5 and 6
$\left(R^{2}=0.81\right)$. As such, with due consideration of the field context and using an appropriate retrieval method for obtaining good-quality samples, an initial guesstimate of the specific gravity of solids $\left(G_{\mathrm{s}}\right)$ could be gleaned from the measured natural water content $\left(w_{\mathrm{n}}\right)$ value. As mentioned earlier, Equations 4-6 relate to peaty soils and peats with von Post $\mathrm{Hn}$ essentially ranging $\mathrm{H} 4$ to H10. It would be interesting for future research to compile an even larger database, to also include fibric ( $\mathrm{H} 1$ to $\mathrm{H} 3$ ) peaty soils and peats, for investigation of the correlation $G_{\mathrm{s}}=\mathrm{f}_{\mathrm{n}}\left(w_{\mathrm{n}}, \mathrm{Hn}\right)$.

\section{Conclusions and recommendations}

This study used original $G_{\mathrm{s}}-N$ data obtained for 25 peaty soils ( $N=$ 23-86\%) retrieved from the Dian-Chi Lake area, Kunming City, China, along with a larger data set comprising 77 peaty clays and peats compiled from various sources in the literature to investigate the $G_{\mathrm{s}}-N$ relationship for estimations of the specific gravity of solids. The following conclusions are drawn from this investigation.

For the total of 102 peaty soils examined with von Post $\mathrm{Hn}$ essentially ranging $\mathrm{H} 4$ to $\mathrm{H} 10$, the best-fit $G_{\mathrm{s}}-N$ correlation given by Equation 1 , with $G_{\mathrm{sm}}=2.77$ and $G_{\mathrm{so}}=1.35$ values deduced in the present study, produces a good fit to the experimental data points. This provides further validation of the correlation originally proposed by Skempton and Petley (1970), for almost identical $G_{\mathrm{sm}}=2.7$ and $G_{\text {so }}=1.4$ values, which was based on data for only 28 peaty soils (H3 to H9).

Weaker inverse bilinear and power relationships were found between the natural water content and specific gravity of solids. Using these approaches, with due consideration of the field context and for goodquality samples, an initial guesstimate of the specific gravity of solids could be gleaned from the measured natural water content value determined on the basis of an oven-drying temperature of $105^{\circ} \mathrm{C}$.

Furthermore, to overcome discrepancies in experimental results caused by procedural differences between relevant codes and for previous experimental work/researchers, it is recommended that an oven-drying temperature of $105^{\circ} \mathrm{C}$ be consistently used for drying the peaty specimens for water content, specific gravity and ignition loss testing, along with an ignition temperature of $440^{\circ} \mathrm{C}$.

Finally, pycnometer tests on peat and other organic soils often employ kerosene (a non-polar solvent), rather than demineralised water, as the liquid in the density bottles. An interesting hypothesis for the evaporated sample's $G_{\mathrm{s}}$ is the potential solubility of some of the organic matter in kerosene, which could lead to differences with the actual value, as organics have specific gravities lower than that of the inorganic solids fraction. This aspect is more relevant to specific gravity testing of, for instance, biosolid and sewage sludge materials whose organic fraction has been identified as a mixture of fats, proteins, carbohydrates, lignin, amino acids, sugars, celluloses, humic material and fatty acids (O'Kelly, 2019). In such cases, calibration of the results against those obtained from water pycnometry tests, or against real values as determined by some methods (e.g. gas pycnometer (ASTM, 2014c)), could be a useful exercise. 


\section{Appendix}

This appendix offers a theoretical background for the correlation between $P$ and $G_{\mathrm{s}}$ for organic soils, considering the general partially saturated condition typical of natural organic deposits that is, the organic soil material consists of inorganic solids, organic solids, water and a gaseous phase (Figure 7). The specific gravities of the inorganic and organic solids $\left(G_{\mathrm{sm}}\right.$ and $G_{\mathrm{so}}$, respectively) can be expressed as follows:

7. $G_{\mathrm{sm}}=\frac{m_{\mathrm{sm}}}{V_{\mathrm{sm}} \rho_{w}}$

8. $G_{\mathrm{so}}=\frac{m_{\mathrm{so}}}{V_{\mathrm{so}} \rho_{\mathrm{w}}}$

where $m_{\mathrm{sm}}$ and $V_{\mathrm{sm}}$ are the dry mass and volume of the inorganic solids, respectively; $m_{\mathrm{so}}$ and $V_{\text {so }}$ are the dry mass and volume of the organic solids, respectively; and $\rho_{\mathrm{w}}$ is the density of water.

Rearranging Equations 7 and 8, the ratio of $G_{\mathrm{so}}$ to $G_{\mathrm{sm}}$ can be expressed as follows:

9. $\frac{G_{\mathrm{so}}}{G_{\mathrm{sm}}}=\left(\frac{m_{\mathrm{so}}}{m_{\mathrm{sm}}}\right) /\left(\frac{V_{\mathrm{so}}}{V_{\mathrm{sm}}}\right)$

Considering a unit mass of dry solids $\left(m_{\mathrm{sm}}+m_{\mathrm{so}}=1\right)$, according to the definition of organic content (expressed as a ratio value, i.e. not $\%$ ), the mass of organic solids is equal to the value of organic matter content - that is, $m_{\mathrm{so}}=P \rightarrow m_{\mathrm{sm}}=1-P$. Then, from Equation 7 , the volume of the inorganic solids is given as $V_{\mathrm{sm}}=(1-P) /\left(G_{\mathrm{sm}} \rho_{\mathrm{w}}\right)$ and the combined volume of inorganic and organic solids is given as

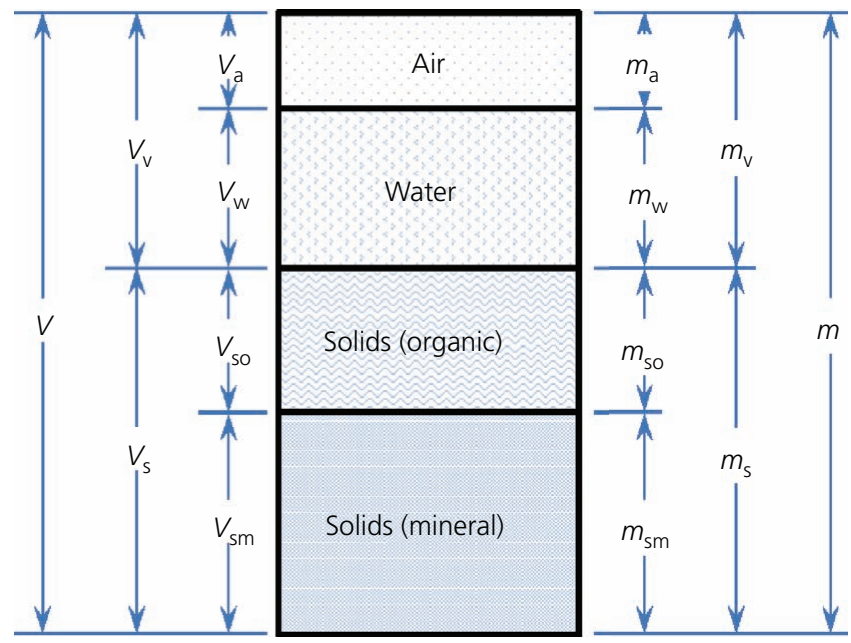

Figure 7. Phase diagram for organic soil expressed in volume and mass fractions
$V_{\mathrm{sm}}+V_{\mathrm{so}}=1 /\left(G_{\mathrm{s}} \rho_{\mathrm{w}}\right)$, where $G_{\mathrm{s}}$ is the specific gravity value based on the combined inorganic and organic solids fractions. Hence, the ratio of $V_{\mathrm{so}}$ to $V_{\mathrm{sm}}$ can be expressed as follows:

10. $\frac{V_{\mathrm{so}}}{V_{\mathrm{sm}}}=\frac{V_{\mathrm{so}}+V_{\mathrm{sm}}}{V_{\mathrm{sm}}}-1=\frac{G_{\mathrm{sm}}}{G_{\mathrm{s}}(1-P)}-1$

Then, Equation 9 can be rewritten as follows:

11. $\frac{G_{\mathrm{so}}}{G_{\mathrm{sm}}}=\left(\frac{P}{1-P}\right) /\left[\frac{G_{\mathrm{sm}}}{G_{\mathrm{s}}(1-P)}-1\right]$

Rearranging, the theoretical relationship between the specific gravity of soil solids $\left(G_{\mathrm{s}}\right)$, its inorganic and organic solids fractions $\left(G_{\mathrm{sm}}\right.$ and $G_{\mathrm{so}}$, respectively) and the organic matter content $(P)$ is given as follows:

12.

$$
G_{\mathrm{s}}=\frac{G_{\mathrm{sm}} G_{\mathrm{so}}}{P\left(G_{\mathrm{sm}}-G_{\mathrm{so}}\right)+G_{\mathrm{so}}}
$$

\section{Acknowledgements}

The research was funded by the National Natural Science Foundation of China $(41572258,41877236,41972275)$ and supported by the Fundamental Research Funds for the Central Universities (22120180093). Assistance with the soil sampling and laboratory testing was provided by C. Pan and H. Zhang, former MSc students in Tongji University, and Y. Li, Y. Cheng, L. Xie and other staff in the 14th Metallurgical Construction of Yunnan Survey and Design Company Ltd.

\section{REFERENCES}

Adams JI (1965) The engineering behavior of a Canadian muskeg. In Proceedings of the 6th International Conference on Soil Mechanics and Foundation Engineering, Montreal, Canada. University of Toronto Press, Toronto, ON, Canada, vol. 1, pp. 3-7.

Al-Raziqi AA, Huat BBK and Munzir HA (2003) Potential usage of hyperbolic method for prediction of organic soil settlement. In Proceedings of the 2nd International Conference on Advances in Soft Soil Engineering and Technology, Putrajaya, Malaysia (Huat BBK, Omar H, Maail S and Mahsun E (eds)). Universiti Putra Malaysia Press, Serdang, Malaysia, pp. 439-445.

ASTM (2014a) D 854-14: Standard test methods for specific gravity of soil solids by water pycnometer. ASTM International, West Conshohocken, PA, USA.

ASTM (2014b) D 2974-14: Standard test methods for moisture, ash, and organic matter of peat and other organic soils. ASTM International, West Conshohocken, PA, USA.

ASTM (2014c) D 5550-14: Standard test method for specific gravity of soil solids by gas pycnometer. ASTM International, West Conshohocken, PA, USA.

BSI (1990a) BS EN 1377-2:1990: Methods of test for soils for civil engineering purposes. Classification tests. BSI, London, UK.

BSI (1990b) BS EN 1377-3:1990: Methods of test for soils for civil engineering purposes. Chemical and electro-chemical tests. BSI, London, UK 
Den Haan EJ and Kruse GAM (2007) Characterisation and engineering properties of Dutch peats. In Proceedings of the 2nd International Workshop on Characterisation and Engineering Properties of Natural Soils, Singapore (Tan TS, Phoon KK, Hight DW and Leroueil S (eds)). CRC Press/Balkema, Leiden, the Netherlands, vol. 3 , pp. 2101-2133

Dhowian AW and Edil TB (1980) Consolidation behavior of peats Geotechnical Testing Journal 3(3): 105-114, https://doi.org/10.1520/ GTJ10881J.

Hobbs NB (1986) Mire morphology and the properties and behaviour of some British and foreign peats. Quarterly Journal of Engineering Geology 19(1): 7-80, https://doi.org/10.1144/GSL.QJEG.1986.019.01.02.

Hosang JR and Locker JG (1971) Discussion of 'Ignition loss and other properties of peats and clays from Avonmouth, King's Lynn and Cranberry Moss'. Géotechnique 21(4): 416-418, https://doi.org/10. 1680/geot.1971.21.4.416.

Huat BBK, Prasad A, Asadi A and Kazemian S (2014) Geotechnics of Organic Soils and Peat. CRC Press/Balkema, Leiden, the Netherlands.

Jommi C, Muraro S, Trivellato E and Zwanenburg C (2019) Experimental results on the influence of gas on the mechanical response of peats. Géotechnique 69(9): 753-766, https://doi.org/10.1680/jgeot.17.P.148.

Kolay PK and Rahman MA (2016) Physico-geotechnical properties of peat and its stabilisation. Proceedings of the Institution of Civil Engineers Ground Improvement 169(3): 206-216, https://doi.org/10.1680/jgrim. 15.00025 .

Landva AO and Pheeney PE (1980) Peat fabric and structure. Canadian Geotechnical Journal 17(3): 416-435, https://doi.org/10.1139/t80-048.

Li W, O'Kelly BC, Fang K and Yang M (2020) Water content determinations of peaty soil using the oven-drying method. Environmental Geotechnics, https://doi.org/10.1680/jenge.18.00056.

Long M and Boylan N (2013) Predictions of settlement in peat soils. Quarterly Journal of Engineering Geology and Hydrogeology 46(3): 303-322, https://doi.org/10.1144/qjegh2011-063.

MacFarlane IC and Allen CM (1965) An Examination of Some Index Test Procedures for Peat. Division of Building Research, National Research Council Canada, Ottawa, ON, Canada, Internal Report No. 314

Madaschi A and Gajo A (2015) One-dimensional response of peaty soils subjected to a wide range of oedometric conditions. Géotechnique 65(4): 274-286, https://doi.org/10.1680/geot.14.P.144.

Mesri G and Ajlouni M (2007) Engineering properties of fibrous peat. Geotechnical and Geoenvironmental Engineering 133(7): 850-866, https://doi.org/10.1061/(ASCE)1090-0241(2007)133:7(850).

Moo-Young HK and Zimmie TF (1996) Geotechnical properties of paper mill sludges for use in landfill covers. Journal of Geotechnical Engineering 122(9): 768-775, https://doi.org/10.1061/(ASCE)07339410(1996)122:9(768).

Ng SY and Eischens GR (1983) Repeated short-term consolidation of peats. In Testing of Peats and Organic Soils (Jarrett PM (ed.)). ASTM, West Conshohocken, PA, USA, ASTM STP 820, pp. 192-206.

O'Kelly BC (2004) Accurate determination of moisture content of organic soils using the oven drying method. Drying Technology 22(7): 1767-1776, https://doi.org/10.1081/DRT-200025642.

O'Kelly BC (2005) New method to determine the true water content of organic soils. Geotechnical Testing Journal 28(4): 365-369, https:// doi.org/10.1520/GTJ11963

O'Kelly BC (2006) Compression and consolidation anisotropy of some soft soils. Geotechnical and Geological Engineering 24(6): 1715-1728, https://doi.org/10.1007/s10706-005-5760-0.

O'Kelly BC (2007) Compressibility and permeability anisotropy of some peaty soils. Proceedings of the 60th Canadian Geotechnical Conference, Ottawa, ON, Canada, vol. 3, pp. 1934-1939.

O'Kelly BC (2008) Effect of biodegradation on the consolidation properties of a dewatered municipal sewage sludge. Waste Management 28(8): 1395-1405, https://doi.org/10.1016/j.wasman.2007.08.004.
O'Kelly BC (2014) Drying temperature and water content-strength correlations. Environmental Geotechnics 1(2): 81-95, https://doi.org/ 10.1680/envgeo.13.00016

O'Kelly BC (2015) Case studies of vacuum consolidation ground improvement in peat deposits. In Ground Improvement Case Histories: Embankments with Special Reference to Consolidation and Other Physical Methods, 1st edn. (Indraratna B, Chu J and Rujikiatkamjorn C (eds)). Butterworth-Heinemann, Oxford, UK, pp. 315-345.

O'Kelly BC (2016) Geotechnics of municipal sludges and residues for landfilling. Geotechnical Research 3(4): 148-179, https://doi.org/10. 1680/jgere.16.00013.

O'Kelly BC (2017) Measurement, interpretation and recommended use of laboratory strength properties of fibrous peat. Geotechnical Research 4(3): 136-171, https://doi.org/10.1680/jgere.17.00006.

O'Kelly BC (2018) Geotechnical laboratory testing and data interpretation for biosolids and sewage sludge. Geotechnical Research 5(4): 247-261, https://doi.org/10.1680/jgere.18.00009.

O'Kelly BC (2019) Biodegradation of biosolids and specific gravity determination. Environmental Geotechnics 6(1): 47-61, https://doi.org/ 10.1680 /jenge. 16.00014 .

O'Kelly BC and Li W (2018) Comparing water contents of organic soil determined on the basis of different oven-drying temperatures. In Proceedings of the China-Europe Conference on Geotechnical Engineering (Wu W and Yu HS (eds)). Springer, Cham, Switzerland, vol. 1, pp. 586-590.

O'Kelly BC and Pichan SP (2013) Effects of decomposition on the compressibility of fibrous peat - a review. Geomechanics and Geoengineering 8(4): 286-296, https://doi.org/10.1080/17486025. 2013.804210.

O'Kelly BC and Pichan SP (2014) Effect of decomposition on physical properties of fibrous peat. Environmental Geotechnics 1(1): 22-32, https://doi.org/10.1680/envgeo.13.00012.

O'Kelly BC and Sivakumar V (2014) Water content determinations for peat and other organic soils using the oven-drying method. Drying Technology 32(6): 631-643, https://doi.org/10.1080/07373937.2013.849728.

O'Loughlin CD and Lehane BM (2003) A study of the link between composition and compressibility of peat and organic soils. In Proceedings of the 2nd International Conference on Advances in Soft Soil Engineering and Technology, Putrajaya, Malaysia (Huat BBK, Omar H, Maail S and Mahsun E (eds)). Universiti Putra Malaysia Press, Serdang, Malaysia, vol. 1, pp. 135-152.

Pankratov TA, Ivanova AO, Dedysh SN and Liesack W (2011) Bacterial populations and environmental factors controlling cellulose degradation in an acidic Sphagnum peat. Environmental Microbiology 13(7): 1800-1814, https://doi.org/10.1111/j.1462-2920.2011.02491.x.

Papadaki E (2013) Modelling of Peat Compressed under Sand Bodies: Experimental and Numerical Approach. Master's thesis, Delft University of Technology, Delft, the Netherlands. See http://resolver. tudelft.nl/uuid:faf79020-4c07-4931-9bf6-dcdbe491bca8 (accessed 18/ 02/2020).

Pichan SP and O'Kelly BC (2012) Effect of decomposition on the compressibility of fibrous peat. In GeoCongress 2012: State of the Art and Practice in Geotechnical Engineering (Hryciw RD, Athanasopoulos-Zekkos A and Yesiller N (eds)). ASCE, Reston, VA, USA, GSP 225, pp. 4329-4338.

Pichan SP and O'Kelly BC (2013) Stimulated decomposition in peat for engineering applications. Proceedings of the Institution of Civil Engineers - Ground Improvement 166(3): 168-176, https://doi.org/10. 1680/grim.12.00003.

Skempton AW and Petley DJ (1970) Ignition loss and other properties of peats and clays from Avonmouth, King's Lynn and Cranberry Moss. Géotechnique 20(4): 343-356, https://doi.org/10.1680/geot.1970.20.4.343.

von Post L and Granlund E (1926) Peat resources in Southern Sweden. Sveriges Geologiska Undersökning (Geological Survey of Sweden) Yearbook 335(19.2 Series C): 1-127. 
Geotechnical Research

Volume 7 Issue 3
Briefing: Specific gravity of solids relationship with ignition loss for peaty soils

Li, O'Kelly, Yang et al.
Wardwell RE, Charlie WA and Doxtader KA (1983) Test method for determining the potential for decomposition in organic soils. In Testing of Peats and Organic Soils (Jarrett PM (ed.)). ASTM International, West Conshohocken, PA, USA, ASTM STP 820, pp. 218-229. Yamaguchi H, Ohira Y, Kogure K and Mori S (1985) Undrained shear characteristics of normally consolidated peat under triaxial compression and extension conditions. Soils and Foundations 25(3): 1-18, https://doi.org/10.3208/sandf1972.25.3_1.

Zhan TL, Zhan Z, Lin W, Luo X and Chen Y (2014) Field and laboratory investigation on geotechnical properties of sewage sludge disposed in a pit at Changan landfill, Chengdu, China. Engineering Geology 170: 24-32, https://doi.org/10.1016/j.enggeo.2013.12.006.

\section{How can you contribute?}

To discuss this paper, please submit up to 500 words to the editor at journals@ice.org.uk. Your contribution will be forwarded to the author(s) for a reply and, if considered appropriate by the editorial board, it will be published as a discussion in a future issue of the journal. 